\title{
A clinical view of mare reproductive physiology
}

\author{
Dale L. Paccamonti and Sara K. Lyle \\ Department of Veterinary Clinical Sciences, Equine Health Studies Program, School of Veterinary Medicine, Louisiana State University, Baton Rouge, LA 70803 (USA)
}

\begin{abstract}
Summary
An understanding of clinically relevant aspects of equine reproductive physiology is helpful to the stud farm practitioner. Anestrus and transition can delay the desired onset of the breeding season and reduce the number of opportunities to establish pregnancy during the season. Although alteration of the photoperiod has long been accepted as the best way to advance the breeding season, recent research may provide additional assistance for hastening the onset of cyclicity. During the breeding season, knowing the pattern of ovulation in mares, both in general and for a particular mare, can be very beneficial in timing insemination for optimum conception rates. Likewise, appreciating the effects of luteolytic agents on aspects of reproductive physiology other than regression of the corpus luteum, such as on follicular development, ovulation, and development of hemorrhagic anovulatory follicles, can assist the clinician in improving breeding efficiency in mares.
\end{abstract}

Keywords: mare, anestrus, ovulation, luteolysis

\begin{abstract}
Klinische Aspekte der Reproduktionsphysiologie der Stute
Das Verständnis klinisch relevanter Aspekte der equinen Reproduktionsphysiologie ist für den Gestütstierarzt hilfreich. Der Winteranöstrus und die Übergangsphase kann den erwünschten Beginn der Zuchtsaison hinauszögern und die möglichen Versuche, eine Trächtigkeit herbeizuführen, reduzieren. Seit langem ist bekannt, dass es mithilfe eines veränderten Lichtregimes möglich ist, den Beginn der Zuchtsaison vorzuverlegen, darüber hinaus bieten nevere Forschungsergebnisse zusätzliche Lösungen, das Einsetzen des Zyklus zu beschleunigen. Während der Zuchtsaison sind Kenntnisse der Erscheinungsbilder der Ovulation bei der Stute, im Allgemeinen sowie für die individuelle Stute, sehr nützlich, den optimalen Zeitpunkt für eine Konzeption zu bestimmen. Zudem betreffen die Effekte lyteolytischer Substanzen auf die Reproduktionsphysiologie nicht nur die Regression des Corpus luteum, sondern auch die Follikelentwicklung, Ovulation und die Entwicklung hämorrhagischer Follikel. Dieses Verständnis kann für den Kliniker hilfreich sein, den Zuchterfolg zu verbessern.
\end{abstract}

Schlüsselwörter: Stute Anöstrus, Ovulation, Luteolyse

\section{Anestrus and transition}

As a group, mares are seasonally polyestrous animals, however great individual variation exists regarding the onset of spring and fall transition and the occurrence and duration of winter anestrus. The onsets of winter anestrus and subsequent spring transition are primarily dependent on photoperiod or day length. Day length of course varies by latitude and mares are more likely to enter anestrus during winter in more extreme latitudes and more likely to cycle year-round in the lower latitudes nearer the equator. The effect of photoperiod is via the pineal gland and through release of melatonin during periods of darkness. Melatonin inhibits secretion of $\mathrm{GnRH}$ from the hypothalamus in the mare. In the autumn, as day length decreases, the duration of melatonin exposure increases and $\mathrm{GnRH}$ output is reduced (Ginther 1992). During the spring, as day length increases, the duration of melatonin secretion decreases, thus leading to an increase in $\mathrm{GnRH}$ release. In response, the anterior pituitary increases secretion of gonadotropins and follicular activity begins. It appears that $\mathrm{LH}$ plays a more critical role than FSH in initiating the onset of cyclicity. During anestrus when GnRH is low, LH is at basal level, while FSH does not change dramatically throughout the year (Thompson Jr. et al. 1986). Although other factors, both systemic and local at the ovarian level, appear to be involved in the onset of anestrus and the resurgence of cyclicity, many questions remain unanswered, as reviewed (Donadeu and Watson 2007).

Whether a mare goes into winter anestrus, and the duration of anestrus, is influenced by factors such as nutrition, age, breed, and temperature. Studies have shown that mares in good body condition are more likely to cycle year around, and those mares in good body condition that do enter into anestrus begin cycling on average a month earlier than mares in poorer body condition (Gentry et al. 2002). Similarly, an increasing plane of nutrition or grazing on green grass is associated with an earlier return to cyclicity (Carnevale et al. 1997, van Niekerk and van Heerden 1972). Older mares tend to begin cycling slightly later than young mares (Vanderwall and Woods 1990), and ponies tend to be more seasonal than horses (Ginther et al. 2004, Sharp 1980). Environmental temperature may modulate the effectiveness of dopamine antagonists, such as sulpiride, used in an attempt to initiate cyclicity. It is often difficult to separate out confounding variables when examining the effect of one variable on the onset of cyclicity. For example, in the spring, as the day lengthens, temperatures are usually on the rise and horses tend to be turned out to graze on spring pastures rather than be kept indoors.

For those mares that do enter winter anestrus, manipulating the photoperiod by providing artificial light to simulate increased day length earlier in the year is an effective method to initiate an earlier return to cyclicity; however mares still go through a period of transition (Sharp et al. 1993). Photoperiod adjustment is usually begun around December 1 in the northern hemisphere. A common scheme is to provide a period of light for 15 to $16 \mathrm{~h}$ (followed by 8 to $9 \mathrm{~h}$ of darkness). This is best accomplished by turning the lights on at the end of the day for a few hours. Alternatively, a short (1 to $2 \mathrm{~h}$ ) peri- 
od of light can be provided during the night (usually 8 or $9 \mathrm{~h}$ after onset of darkness) to interrupt the duration of the melatonin influence, as reviewed (McCue et al. 2007).

If mares are observed closely via ultrasonography as they come out of anestrus and enter the transitional period, multiple waves of follicular growth and regression will be seen. Sharp et al. (1993) reported that pony mares in Florida had, on average, 3.7 follicular waves before the first ovulation of the year. The early follicles are not steroidogenically competent and increases in serum estrogen concentration do not accompany these waves. They can, however, produce low levels of estrogen sufficient to cause estrous behavior. During this transitional period, estrous behavior exhibited by a mare can be very erratic. Transition may last for weeks or months and mares may exhibit prolonged periods of estrus, interspersed with variable periods of passivity or rejection of the stallion. This presents a frustrating and sometimes confusing situation for horse owners that desire to get their mare bred early in the season. When a mare is in obvious estrus, it would seem to be advisable to breed her if pregnancy is desired. However breeding a mare in transition is a waste of the stallion's semen and farm personnel's time. An additional problem is that repeated breeding during transition can actually decrease the chances of getting a problem mare in foal. The repeated deposition of semen into the uterus of a mare with impaired fertility and the resulting inflammation from each breeding can exacerbate an already tenuous situation.

As the period of transition progresses and the developing follicles increase in size, they eventually become steroidogenically competent and produce detectable levels of estrogen approximately a week prior to the first ovulation (McCue et al. 1992). The estrogen stimulates production of $\mathrm{LH}$ from the pituitary and the eventual $\mathrm{LH}$ surge will result in maturation and ovulation of a dominant follicle.

Researchers have investigated many ways to shorten transition and advance the onset of cyclicity in order to expedite getting mares pregnant earlier in the year. Any treatment is less likely to be effective if a mare is in deep anestrus. As spring progresses or the more advanced a mare is into transition, the more likely a treatment is to be successful. Attempts to induce ovulation during transition by pharmacological means have not been routinely successful. Use of deslorelin in late transitional mares advanced the date of first ovulation by approximately two weeks, but repeated injections were needed (McKinnon et al. 1997). Dopamine antagonists have been used successfully to advance cyclicity in some reports. When mares were pretreated with estrogen, sulpiride treatment resulted in mares ovulating earlier than controls (Kelley et al. 2006). Similarly, estrogen treatment enhanced the ability of domperidone to advance cyclicity (Mitcham et al. 2009). In another report, sulpiride successfully hastened the onset of cyclicity and the establishment of pregnancy, whereas treatment with domperidone had no effect (Mari G. 2009). However, the formulation and dose of domperidone in these reports were quite different. Nutrition should not be overlooked because body condition has been shown to be correlated with the onset of cyclicity (Gentry et al. 2002, Waller et al. 2006). A combination of altered photoperiod, good nutrition and dopamine antagonist after estrogen priming may be a useful means to initiate earlier cyclicity and advance the breeding season.

\section{Ovulation}

Once cyclicity begins, mares normally ovulate every 21 to 22 days. Diestrus is the most consistent phase of the cycle, lasting 14 to 15 days, with no seasonal variation. Estrus, on the other hand, is more variable, usually lasting somewhat longer (e.g. 5 to $7 \mathrm{~d}$ ) earlier in the season and being shorter (e.g. 4 to 5 d) nearer the summer solstice. The duration of estrus also varies between individual mares and varies depending on the size of follicles that are present at the onset of estrus.

A factor that complicates the veterinarian's job of breeding management is that unlike most of our other domestic species that ovulate a set time after the onset of estrus, mares ovulate at variable times after the onset of estrus, and continue to display estrous behavior for a day or two after ovulation. With the other species, it is easy to detect the onset of estrus and time artificial insemination or breeding based on that time point. However, with mares, this may not result in a high overall conception rate. For best results, especially when using cooled or frozen semen, follicular development during estrus must be monitored and insemination or breeding timed to occur near ovulation.

No single criterion to accurately predict ovulation has proven to be reliable. As ovulation nears, follicular size and softness increase and the ultrasonographic image has a characteristic appearance. The apparent softness of a follicle may vary by its location on the ovary. Maximum size of a follicle prior to ovulation is often greater early in the season, but varies between mares. One aspect of ovarian activity that is helpful in breeding management is that mares were found to ovulate from consistent follicular diameters in consecutive cycles (Cuervo-Arango and Newcombe 2008). Therefore, it was suggested that follicular diameters recorded from previous ovulations can be relied on to predict the optimal breeding time in successive cycles especially in mares that ovulate from unusually small follicles (Cuervo-Arango and Newcombe 2008). It should also be noted that mares treated with an ovulation-inducing agent will ovulate a follicle of a smaller diameter than if allowed to ovulate spontaneously (CuervoArango and Newcombe 2008). One factor to remember is that regressing follicles are refractory to attempts to induce ovulation. Regressing follicles may be difficult to identify on the basis of a single examination. Follicular regression is slower than growth and regressing follicles remain palpable and visible ultrasonographically for several days.

Whether mares are more likely to ovulate at a given time of day, i.e. whether there is a diurnal pattern to ovulation is unclear. Many studies have looked at this issue but most have either checked mares infrequently or used very small groups of mares. Two recent studies have come to different conclusions. Newcombe (Newcombe 2008) reported a lack of a diurnal pattern to ovulation. However, in that study mares were examined at various times of day at intervals up to 8.5 $h$, and some mares had estrus induced with prostaglandins. Nevertheless, although he concluded there was no diurnal pattern, there was a reported incidence of ovulation between $14: 00$ to $22: 00$ h of $44.3 \%$ vs. an expected $33.3 \%$. Bradecamp et al. (2005) examined 25 mares at $2 \mathrm{~h}$ intervals during a naturally occurring estrus and found that mares tended to ovulate between 16:00 to 24:00 h, similar to the Newcombe 
report. A subsequent study by the same group examined the effect of hCG given at 08:00 or 20:00 on altering the time of ovulation. The effect of hCG overrode any diurnal pattern, and mares ovulated 34 to $40 \mathrm{~h}$ after hCG regardless if administration was in the morning or the night.

\section{Anovulatory follicles}

Occasionally a dominant follicle fails to ovulate at the end of estrus. Although anovulatory follicles are more common early or late in the season, they are sometimes observed during the normal breeding season, especially in older mares (Ginther et al. 2007a). These non-ovulatory follicles have been called hemorrhagic anovulatory follicles (HAF), anovulatory hemorrhagic follicles, hemorrhagic follicles or persistent anovulatory follicles. Using grey-scale B-mode ultrasonography, there are no premonitory signs that can be used to predict that a follicle will fail to ovulate. Typically, an HAF can be recognized by the sudden appearance of an abundance of hyperechoic floating specks in the antrum of the follicle. Over the next few days, hyperechoic strands are observed to develop in the antrum and the wall of the follicle thickens as apparent luteal tissue develops. No significant difference in concentrations of progesterone or $\mathrm{LH}$ was found between mares that developed an HAF and control mares that ovulated, and only a slightly greater concentration of estrogen in the mares with HAF was observed 3 d before formation (Ginther et al. 2007a). Although the cause of HAF remains unknown, recent work has revealed a relative lack of angiogenic activity in HAF compared to corpora lutea formed after ovulation (Ellenberger et al. 2009). Some mares are prone to repeated occurrences of HAF and some researchers feel that conditions such as laminitis may contribute to the occurrence of an HAF (Cuervo-Arango and Newcombe 2009a, Cuervo-Arango and Newcombe 2009b, Ginther et al. 2007a). Additionally, there are a number of recent reports linking the use of cloprostenol to induce luteolysis and a return to estrus with an increased risk of formation of HAFs (Cuervo-Arango and Newcombe 2009a, Cuervo-Arango and Newcombe 2009b).

\section{Luteolysis}

Another characteristic of mares that may complicate breeding management is the propensity to grow large follicles during diestrus. Although these follicles usually regress, they can ovulate during diestrus. The effect of a diestrous ovulation on interestrous interval depends on when it occurs in relation to the endogenous release of PGF that initiates luteolysis and the end of diestrus. If a mare ovulates late enough in diestrus that when PGF is released from the endometrium the 'new' corpus luteum is unable to respond to the PGF, it will continue to secrete progesterone, causing a prolonged diestrous period. The effect of this situation is most significant when a presumptive pregnancy diagnosis is based on estrus detection rather than ultrasonographic examination.

In ruminants luteolysis is a local mechanism dependent on a countercurrent exchange mechanism; however, in mares the PGF released from the endometrium reaches the ovaries through a systemic route. This is important when considering maternal recognition of pregnancy. A clinically significant ramification of this is that when transferring an embryo, the embryo can be deposited within either uterine horn without regard to side of ovulation. Another consequence is that for maternal recognition of pregnancy to be effective, the embryo must come into contact with the entire uterus in order to prevent PGF release that would result in luteolysis. The embryo achieves this by having a high degree of mobility until approximately 16 days of gestation. Impediments to embryo migration (cysts, strictures) can result in a failure of maternal recognition of pregnancy and a return to estrus.

Following ovulation, progesterone begins to rise almost immediately, reaching a peak around $8 \mathrm{~d}$ after ovulation, which is followed by a gradual decline until luteolysis. Ultrasonographically, the cross sectional area of the corpus luteum begins to decline gradually as early as $4 \mathrm{~d}$ post ovulation (Ginther et al. 2007b). At the time of luteolysis, progesterone declines precipitously, more rapidly than the area of the $\mathrm{CL}$. An increase in echogenicity of the $C L$ is commonly observed at luteolysis, and the CL can still be visualized ultrasonographically for a few days after luteolysis.

The corpus luteum $(\mathrm{CL})$ is usually considered responsive to PGF beginning 5 or $6 \mathrm{~d}$ after ovulation. However, the sensitivity of the CL to exogenous PGF depends on the individual mare, the time of administration in relation to ovulation, the dose of PGF, and possibly even the particular analogue used. In an early study on the action of PGF, $10 \mathrm{mg}$ of PGF administered one or two days after ovulation had no effect on the cycle length. When the same dose of PGF was given on the third day after ovulation, $40 \%$ of treated mares returned to estrus within four days. All mares responded when treated on day five or later (Oxender et al. 1975). This demonstrates the developing sensitivity of the maturing $\mathrm{CL}$ to PGF, with some mares responding to PGF as early as $3 d$ post ovulation. A more recent report confirmed the susceptibility of the early $\mathrm{CL}$ in some mares to pharmacologic doses of PGF (Rubio et al. 2008). The administration of 10 mg PGF to mares on days 0,1 and 2 after ovulation resulted in 4 of 6 mares ovulating again just $7 \mathrm{~d}$ after the initial ovulation, while the other 2 mares had a resulting prolonged anovulatory period. (Rubio et al. 2008)

The recommended dose of PGF varies widely. While 5 or 10 $\mathrm{mg}$ is commonly recommended, numerous studies have demonstrated the efficacy of much smaller doses. A single dose of $1.25 \mathrm{mg}$ PGF during diestrus caused progesterone to decline to $<1 \mathrm{ng} / \mathrm{mL}$ in two days (Barker C. et al. 2006). Similarly, 2 doses of $0.5 \mathrm{mg}$ PGF given $24 \mathrm{~h}$ apart were found to be as effective as a single $10 \mathrm{mg}$ dose, but resulted in fewer side effects (Irvine et al. 2002).

The interval from PGF administration to estrus and ovulation can be quite variable. Both the dose of PGF used and the presence of follicles on the ovaries can affect the response. During diestrus, luteal progesterone slows the $\mathrm{GnRH}$ pulse frequency and inhibits the LH surge. Exogenous PGF induces luteolysis and removes the brake on the $\mathrm{GnRH}$ pulse generator. The resulting accelerated pulse frequency induces an $\mathrm{LH}$ surge that may cause ovulation of a large growing follicle within 2 d (Newcombe et al. 2008). Estrus may be immediate and brief, so brief in fact, that it may go unnoticed. The next observed estrus is then in $15 \mathrm{~d}$, with ovulation some days later. In this case, it may appear that there was an apparent failure to induce estrus. Alternatively, if the only significant fol- 
licle present at the time of PGF administration has already begun the process of atresia, this process cannot be reversed and a new follicle must develop. In this case, ovulation may also be delayed past what is considered "normal". Newcombe et al. (2008) although using different doses of cloprostenol at different stages of the estrous cycle, reported that the shortest interval to ovulation was found in mares with large follicles present when they received $625 \mathrm{ug}$ of cloprostenol, with $60 \%$ ovulating within $2 \mathrm{~d}$. Repeated low doses, or a slow low dose infusion, being more physiologic than a single bolus (Ginther et al. 2009), may provide a more predictable response. Ginther recently reported (Ginther and Al-Mamun 2009) that mares receiving $5 \mathrm{mg}$ PGF to induce estrus were more likely to have either a double ovulation or an ovulation plus an HAF than mares with a naturally occurring estrus. It is possible that a more predictable outcome may result by reducing the dose of PGF or cloprostenol and monitoring the status of the ovaries at the time of administration. Clearly, understanding underlying mechanisms of reproductive physiology can not only help to explain unexpected occurrences to clients, but help the clinician to establish a basis for a sound treatment plan to improve breeding management.

\section{References}

Barker C., Echeverria K., Davis M., Whisnant C. S. and Pinto C. R. F. (2006) Effects of different doses of PGF2 on luteal function and on the subsequent estrous cycle. Anim. Reprod. Sci. 94, 207-209

Bradecamp E. A., Lyle S. K., Eilts B. E. and Paccamonti D. L. (2005) Determination of the time of day of spontaneous ovulation in the mare. Theriogenology 64, 781

Carnevale E. M., Hermenet M. J. and Ginther O. J. (1997) Age and pasture effects on vernal transition in mares. Theriogenology 47 , 1009-1018

Cuervo-Arango J. and Newcombe J. R. (2008) Repeatability of preovulatory follicular diameter and uterine edema pattern in two consecutive cycles in the mare and how they are influenced by ovulation inductors. Theriogenology 69, 681-687

Cuervo-Arango J. and Newcombe J. R. (2009a) The effect of hormone treatments ( $h C G$ and cloprostenol) and season on the incidence of hemorrhagic anovulatory follicles in the mare: A field study. Theriogenology 72, 1262-1267

Cuervo-Arango J. and Newcombe J. R. (2009b) The effect of cloprostenol on the incidence of multiple ovulation and anovulatory hemorrhagic follicles in two mares: A case report. J. Eq. Vet. Sci. $29,533-539$

Donadeu F. X. and Watson E. D. (2007) Seasonal changes in ovarian activity: Lessons learnt from the horse. Anim.Reprod.Sci. 100, 225-242

Ellenberger C., Muller K., Schoon H. A., Wilsher S. and Allen W. R. (2009) Histological and Immunohistochemical Characterization of Equine Anovulatory Haemorrhagic Follicles (AHFs). Reprod. Dom. Anim. 44, 395-405

Gentry L. R., Thompson D. L. J., Gentry G. T. J., Davis K. A., Godke R. A. and Cartmill J. A. (2002) The relationship between body condition, leptin, and reproductive hormonal characteristics of mares during the seasonal anovulatory period. J. Anim. Sci. 80, 2695-2703

Ginther O. J. (1992) Reproductive Biology of the Mare, ed. Equiservices, Cross Plains

Ginther O. J. and Al-Mamun M. (2009) Increased frequency of double ovulations after induction of luteolysis with exogenous prostaglandin F2 $\alpha$. J. Eq. Vet. Sci. 29, 581-583

Ginther O. J., Gastal E. L., Gastal M. O. and Beg M. A. (2004) Seasonal influence on equine follicle dynamics. Anim. Reprod. 1, 31-44

Ginther O. J., Gastal E. L., Gastal M. O. and Beg M. A. (2007a) Incidence, endocrinology, vascularity, and morphology of hemorrhagic anovulatory follicles in mares. J. Eq. Vet. Sci. 27, 130-139
Ginther O. J., Gastal E. L., Gastal M. O., Utt M. D. and Beg M. A. (2007b) Luteal blood flow and progesterone production in mares. Anim. Reprod. Sci. 99, 213-220

Ginther O. J., Siddiqui M. A. R. and Beg M. A. (2009) Physiologic and nonphysiologic effects of exogenous prostaglandin F2[alpha] on reproductive hormones in mares. Theriogenology 72, 417-424

Irvine C. H. G., McKeough V. L., Turner J. E., Alexander S. L. and Taylor T. B. (2002) Effectiveness of a two-dose regimen of prostaglandin administration in inducing luteolysis without adverse side effects in mares. Eq. Vet. J. 34, 191-194

Kelley K. K., Thompson J., Storer W. A., Mitcham P. B., Gilley R. M. and Burns P. J. (2006) Estradiol interactions with dopamine antagonists in mares: Prolactin secretion and reproductive traits. J. Eq. Vet. Sci. 26, 517-528

Mari G., Morganti M., Merlo B., Castagnetti C., Parmeggiani F., Govoni N., Galeati G. and Tamanini C. (2009) Administration of sulpiride or domperidone for advancing the first ovulation in deep anestrous mares. Theriogenology 71, 959-965

McCue P. M., Logan N. L. and Magee C. (2007) Management of the transition period: physiology and artificial photoperiod. Eq. Vet. Educ. 146-150

McCue P. M., Warren R. C., Appel R. D., Stabenfeldt G. H., Hughes, J. P. and Lasley B. L. (1992) Pregnancy rates following administration of GnRH to anestrous mares. J. Eq. Vet. Sci. 12, 21-23

McKinnon A. O., Vasey J. R., Lescun T. B. and Trigg T. E. (1997) Repeated use of a $\mathrm{GnRH}$ analog deslorelin (Ovuplant) for hastening ovulation in the transitional mare. Eq. Vet. J. 29, 153-155

Mitcham P. B., Thompson J., Thompson T., Bennett S. D., Burns P. J. and Caltabilota T. J. (2009) Estradiol and domperidone stimulation of ovulation in mares in winter: Dose and combination studies. J. Eq. Vet. Sci. 29, 341-342

Newcombe J. R. (2008) Absence of any specific diurnal pattern in the time of ovulation in the mare. J. Eq. Vet. Sci. 28, 427-430

Newcombe J. R., Jochle W. and Cuervo-Arango J. (2008) Effect of dose of cloprostenol on the interval to ovulation in the diestrous mare: A retrospective study. J. Eq. Vet. Sci. 28, 532-539

Oxender W. D., Noden P. A., Bolenbaugh D. L. and Hafs H. D. (1975) Control of estrus with prostaglandin F2 $\alpha$ in mares: Minimal effective dose and stage of estrous cycle. Am. J. Vet. Res. 36, 1145-1 147

Rubio C., Pinto C. R. F., Holland B., da Silva B., Layne S., Heaton L. and Whisnant C. S. (2008) Anti-luteogenic and luteolytic effects of PGF2 during the post-ovulatory period in mares. Theriogenology 70, 587-587

Sharp D. C. (1980) Environmental influences on reproduction in horses. Vet.Clin.N.Am.: Large Anim. Pract. 2, 207-223

Sharp D. C., Cleaver B. D. and Davis S. D. (1993) Photoperiod. In: Equine Reproduction, eds. , McKinnon A. O. and Voss J. L., Williams \& Wilkins, Baltimore, 179-185

Thompson Jr. D. L., Johnson L., St George R. L. and Garza F. (1986) Concentrations of prolactin, luteinizing hormone and follicle stimulating hormone in pituitary and serum of horses: effect of sex, season and reproductive state. J. Anim. Sci. 63, 854-860

van Niekerk C. H. and van Heerden J. S. (1972) Nutrition and ovarian activity of mares early in the breeding season. J. S. Afr. Vet. Assoc. 43, 355-360

Vanderwall D. K. and Woods G. L. (1990) Age-related subfertility in the mare. Proc. Am. Assoc. Eq. Pract. 37, 85-89

Waller C. A., Thompson J., Cartmill J. A., Storer W. A. and Huff N. K. (2006) Reproduction in high body condition mares with high versus low leptin concentrations. Theriogenology 66, 923-928

Dale L. Paccamonti

Department of Veterinary Clinical Sciences,

Equine Health Studies Program

School of Veterinary Medicine,

Louisiana State University,

Baton Rouge, LA 70803 (USA)

pacc@Isu.edu 